\title{
Rapid authenticity testing of artificially bred green turtles (Chelonia mydas) using microsatellite and mitochondrial DNA markers
}

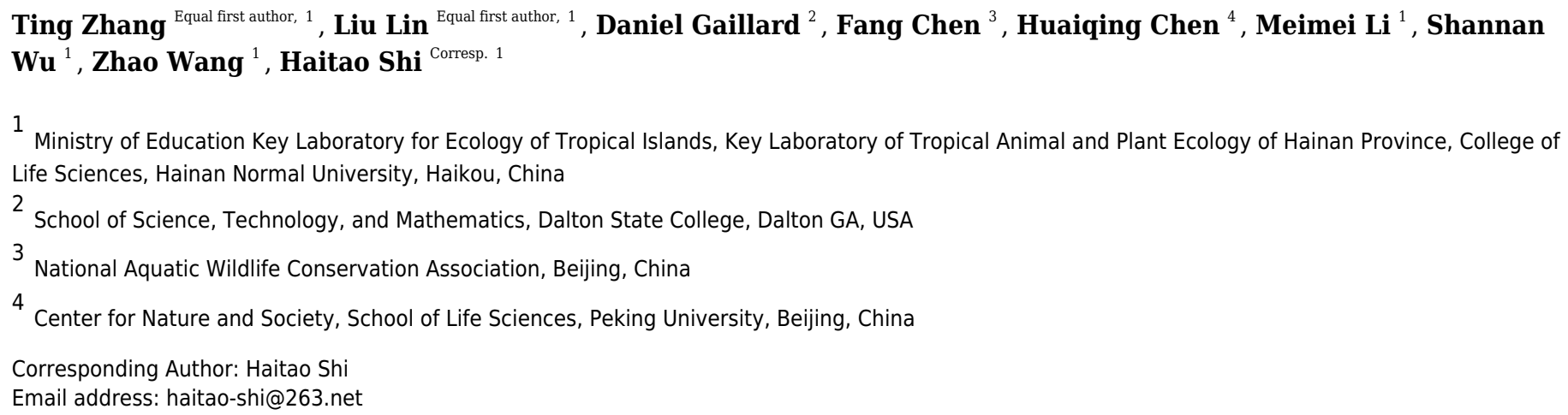

Sea turtles are threatened by climate change and human activity, and their global populations continue to decline sharply. The Chinese government encourages artificial breeding of sea turtles to reduce the use of wild populations. However, artificial breeding of sea turtles is still fairly difficult, and some facilities may illegally purchase wild turtle eggs and then sell incubated turtles by marketing them as artificially bred turtles, which adds another threat to an already endangered species. Therefore, it is necessary to find a reliable method to distinguish the authenticity of artificially bred individuals. In this study, we investigated a turtle farm in southern China, that contained more than 400 green turtles, which were claimed to have been bred in captivity. Parentage testing of turtles from this farm was successfully conducted using two nuclear microsatellites combined with a mitochondrial D-loop DNA marker. Genetic matching of all 19 adults and randomly selected 16 juvenile turtles revealed that none of the juvenile turtles had a matching parent combination among the adult turtles. Therefore, we speculated that the green turtles in this farm were from the wild and that their origin of birth was mainly the Sulu Sea. The methods and molecular markers used in this study could be a reference for rapid authenticity testing of green turtles in future forensic enforcement and population management. 


\section{Rapid authenticity testing of artificially bred green turtles (Chelonia}

\section{2 mydas) using microsatellite and mitochondrial DNA markers}

3 Ting Zhang ${ }^{1 \#}$, Liu Lin ${ }^{1 \#}$, Daniel Gaillard ${ }^{2}$, Fang Chen ${ }^{3}$, Huaiqing Chen ${ }^{4}$, Meimei Li ${ }^{1}$, Shannan

$4 \mathrm{Wu}^{1}$, Zhao Wang ${ }^{1}$, Haitao $\mathrm{Shi}^{1 *}$

$5 \quad{ }^{1}$ Ministry of Education Key Laboratory for Ecology of Tropical Islands, Key Laboratory of

6 Tropical Animal and Plant Ecology of Hainan Province, College of Life Sciences, Hainan

7 Normal University, Haikou 571158, China.

8 2School of Science, Technology, and Mathematics, Dalton State College, 650 College Drive,

9 Dalton GA 30720, USA.

$10{ }^{3}$ National Aquatic Wildlife Conservation Association, Room 705 Beijing Agricultural Exhibition

11 Road toward the No. 5 Building Chaoyang District, Beijing, China.

$12{ }^{4}$ Center for Nature and Society, School of Life Sciences, Peking University, Beijing 100871,

13 China.

14 \# Joint first author.

$15 *$ Corresponding author. Email: haitao-shi@263.net

\section{Abstract}

18 Sea turtles are threatened by climate change and human activity, and their global 
of sea turtles to reduce the use of wild populations. However, artificial breeding of sea turtles is still fairly difficult, and some facilities may illegally purchase wild turtle eggs and then sell incubated turtles by marketing them as artificially bred turtles, which adds another threat to an already endangered species. Therefore, it is necessary to find a reliable method to distinguish the authenticity of artificially bred individuals. In this study, we investigated a turtle farm in southern China, that contained more than 400 green turtles, which were claimed to have been bred in captivity. Parentage testing of turtles from this farm was successfully conducted using two nuclear microsatellites combined with a mitochondrial D-loop DNA marker. Genetic matching of all 19 adults and randomly selected 16 juvenile turtles revealed that none of the juvenile turtles had a matching parent combination among the adult turtles. Therefore, we speculated that the green turtles in this farm were from the wild and that their origin of birth was mainly the Sulu Sea. The methods and molecular markers used in this study could be a reference for rapid authenticity testing of green turtles in future forensic enforcement and population management.

Keywords: Green turtles (Chelonia mydas); Parentage identification; Microsatellite DNA; Mitochondria DNA.

\section{Introduction}

Sea turtles are umbrella species of the marine ecosystem and flagship species of marine conservation (Bouchard \& Bjorndal, 2000; Hamann et al., 2010). However, the global population and distribution of the sea turtle have sharply reduced due to long-term threats, such 
40 as over-exploitation, illegal trade, marine pollution, and climate change (Chan et al., 2007;

41 Hawkes et al., 2009; Lam et al., 2011). All five sea turtle species distributed in China have been

42 included in the list of Chinese National Fist-Level Key Protected Wild Animals and the appendix

43 I of Convention on International Trade in Endangered Species of Wild Fauna and Flora (CITES),

44 indicating that sea turtles are strictly protected and the international trade of these species is

45 prohibited except when the purpose of the import is not commercial.

46 The fast-growing demand for sea turtle displays from Chinese aquariums and private

47 individuals has led to a large-scale illegal trade of live turtles, seriously threatening the survival

48 of wild sea turtles (Lin et al., 2021). The Chinese government issued the "Sea Turtle

49 Conservation Action Plan (2019-2033)" in 2018 and the plan recommended "strengthening

50 research on the technology of artificial breeding of sea turtles and promoting the use of artificial

51 breeding sea turtles for aquarium display, publicity, and education to reduce human demand for

52 sea turtles in the wild" (Ministry of Agriculture and Rural Affairs of China, 2019). Therefore, the

53 number of institutions for artificial breeding of sea turtles is expected to gradually increase in

54 China. However, artificial breeding of sea turtles is still fairly difficult and only a few successful

55 cases have been reported worldwide, such as the Cayman Islands, UK (Barbanti et al., 2019),

56 Miami Seaquarium, FL, USA (Sizemore, 2002), Sea Life Park, Hawaii, USA (Wood \& Wood,

57 1980), and Ishigaki Island in Japan (Shimizu et al., 2007). In China, only the Huidong Turtle

58 National Nature Reserve in Guangdong and Haichang Whale Shark Aquarium in Shandong have

59 successfully bred turtles using wild parent turtles under captive conditions (Gao et al., 2015; Li

60 et al., 2016). Due to inefficient breeding methods, some facilities illegally purchased wild turtle 
61

62

eggs from the South China Sea or Southeast Asia, and then sold the incubated turtles to aquariums or private organizations by marketing them as artificially bred turtles (Shanker \& Pilcher, 2003; Lam et al., 2011). It is well-known that turtle farms are usually the biggest purchasers of wild turtles in China (Shi et al., 2007), and the origins of many turtles in captivity breeding and trade are false or unclear (Parham \& Shi, 2001; Parham et al., 2001) . Therefore, to prevent the illegal use of wild populations, it is necessary to develop reliable methods to distinguish the authenticity of artificially bred sea turtles in forensic enforcement and population management.

DNA analysis methods have been widely used in wildlife forensic enforcement. Among these methods, the nuclear microsatellite gene is widely used in molecular marker-assisted breeding and parentage test of captive animals; it has the advantages of high variability and polymorphism, as well as codominance (Schlötterer \& Pemberton, 1994). The nuclear microsatellite gene can be stably passed from one generation to the other, that is, half of the genetic material of the offspring is contributed by the father and half by the mother. Therefore, on a specific microsatellite locus, two alleles of the offspring should be found in the genotype of the father or the mother, otherwise, they do not have a parent-offspring relationship (Huang \& Wang, 2004; Yang \& Liu, 2014; Zhang et al., 2018). Mitochondrial sequences have the characteristics of maternal inheritance and the offspring will have the same haplotype of the mitochondrial gene as the mother. Sea turtles are highly loyal to their birthplace and female adults return to their hatchling beach to lay their eggs. Thus, turtles from the same birthplace share unique haplotypes of the mitochondrial gene (Bowen et al., 1992; Nishizawa et al., 2011). 
82 Therefore, the mitochondrial gene can be used to identify the birthplace of sea turtles, as well as

83 the mother-child relationship between a baby turtle and an adult female. The combination of

84

85

86

87

microsatellite and mitochondrial DNA markers could be used to rapidly exclude the parentage relationship and also trace the source of illegal trade or capture in forensic enforcement for the authenticity of artificially bred animals.

In 2019, a turtle farm in southern China claimed that six captive adult green turtles (four females and two males) had successfully been reproduced and more than 400 baby turtles hatched between 2015 and 2017. Although the farm has the breeding license, the success of artificial reproduction could not be verified, since it is not possible to provide evidence of sea turtle breeding, mating, and egg laying. To verify this, we collected skin samples from 19 adult turtles, including the above six potential parents, and 16 juvenile turtles randomly selected. The mitochondrial D-loop gene and two microsatellite loci were jointly sequenced and analyzed to detect whether a parent-offspring relationship existed between adult and juvenile turtles and to infer the birthplaces of these turtles.

\section{Materials \& Methods}

\subsection{Sample collection and DNA extraction}

Skin samples of sea turtles were collected form their hind limbs and disinfected with iodophor (LIRCON, Shandong, China) after sampling. The sex of adult individuals was identified according to the length of the tail (Zhang et al., 1995). All samples were stored in $95 \%$ alcohol between $15-25^{\circ} \mathrm{C}$. The sample collection in this work has been approved by the Chinese 
102

103

104

105

106

107

108

109

110

111

112

113

114

115

116

117

118

119

120

121

government, and this work was conducted in strict accordance with the guidelines of the Animal

Research Ethics Committee of Hainan Provincial Education Centre for Ecology and

Environment, Hainan Normal University (HNECEE-2012-005).

DNA was extracted using a Tiangen Blood/Cell/Tissue Genomic DNA Extraction Kit

(TIANamp Genomic DNA Kit, Beijing, China), following the manufacturer's protocol. DNA

concentration and quality were tested using a NanoDropTM One/OneC

spectrophotometer (Thermo Fisher, MA, USA).

\subsection{Amplification and detection of gene loci}

The primers LCM15382 (5'-GCTTAACCCTAAAGCATTGG-3') and H950g (5'-

AGTCTCGGATTTAGGGGTTTG-3') of the mitochondrial D-loop were used for this study, and the length of the amplified product was 770 bp (Yang, 2015; Wei, 2016).

The two microsatellite loci B103 and D1 are markers previously developed for green turtles, and these loci have high genetic diversity and were sufficient to ensure accuracy of the discrimination results (Table S1; Dutton \& Frey, 2010). Using an online tool

(http://www.primer-dimer.com/), we detected that these two pairs of primers did not dimerize;

therefore, different fluorescent dye labels (TAMRA and FAM) were used, and the two pairs of primers were separately subjected to PCR and multiplex PCR to obtain two independent replicates.

The PCR amplification mixture $(50 \mu \mathrm{l})$ contained $2 \times$ Taq mix (RN03001S, MonAmp $\left.{ }^{\mathrm{TM}}\right)$, $25 \mu \mathrm{l}$; template DNA, $2 \mu \mathrm{l} ; 10 \mu \mathrm{M}$ primer dilutions, each $2 \mu \mathrm{l}$, amonng multiplex PCR contains 
122

123

124

125

126

127

128

129

130

131

132

133

134

135

136

137

138

139

140

141

two10 $\mu \mathrm{M}$ primer dilutions (B103 and D1), $2 \mu 1$ each; supplemented with ultrapure water to 50

$\mu 1$. PCR conditions were as follows: pre-denaturing at $94^{\circ} \mathrm{C}$ for $3 \mathrm{~min}$; followed by 35 cycles of denaturing at $94{ }^{\circ} \mathrm{C}$ for $40 \mathrm{~s}$, annealing at $55^{\circ} \mathrm{C}$ for $40 \mathrm{~s}$, extension at $72{ }^{\circ} \mathrm{C}$ for $30 \mathrm{~s}$; a final

extension at $72{ }^{\circ} \mathrm{C}$ for $4 \mathrm{~min}$; and storage at $4{ }^{\circ} \mathrm{C}$. To prevent fluorescence primers from

quenching, the samples were protected from light. Precisely, $5 \mu \mathrm{l}$ of PCR product was loaded,

and a $1 \%$ agarose gel was used for electrophoresis at $120 \mathrm{~V} / \mathrm{cm}$ for $20 \mathrm{~min}$, with Marker DL2000

(TIANamp, Beijing, China) as a reference. After the electrophoresis, the agarose gel was placed

in a Molecular Imager ${ }^{\circledR}$ ChemiDoc ${ }^{\mathrm{TM}}$ XRS + Imaging System (BIO-RAD, MA, USA ) to capture images. PCR products were submitted to Guangzhou Qingke Technology Co., Ltd. for the firstgeneration sequencing of D-loop gene fragments and microsatellite loci typing. Amplicons were purified and sequenced in both directions using BigDye on an ABI 3730XL sequencing system (Applied Biosystems, Foster, CA, USA) (Gaillard et al., 2020). And microsatellite allele sizes were estimated in $2 \mu \mathrm{L}$ of diluted amplified DNA, $0.5 \mu \mathrm{L}$ of GeneScanTM 500 Liz Size standard (Applied Biosystems) and $12.5 \mu \mathrm{L}$ of deionized formamide on an ABI 3000 DNA Analyzer (Applied Biosystems), and alleles assigned using GeneMapper ${ }^{\circledR}$ software (version 3.7, Applied Biosystems) and GeneScan 500 ROX fluorescent size standard (Applied Biosystems) (Barbanti et al., 2019).

\subsection{Parentage testing}

In this study, we adopted the direct exclusion method of forensic science to distinguish the authenticity of artificially bred individuals as follows: 1 . If the adult female turtle did not carry 
142 the same haplotype as the juvenile turtle on the mitochondrial D-loop segment, it was excluded 143 as the parent of the juvenile individual; 2. if an adult male or female turtle did not carry at least

144 one matching allele in each of the microsatellite loci as the juvenile turtle, it was excluded as the 145 parent of the juvenile individual; 3. adult individuals were paired using the microsatellite 146 genotypes after the first two steps of screening. If the combination matched the juvenile 147 individuals' microsatellite genotypes, then the corresponding male and female individuals were 148 considered as potential parents.

\subsection{Mixed-stock analysis}

To determine stock contributions for the all turtles in the present study, we used a Bayesian MSA analyses each for the juvenile and adult datasets. We used the same haplotype frequencies as that of Australasian nesting rookeries, according to Gaillard et al. (2020). We used both uniform priors (UP) and an informative priors (IP) analysis, as reported by Dethmers et al. (2010) to determine stock contributions. For each analysis, 30 chains were run with 100,000 MCMC for every chain. For each chain in the UP analysis, a different stock was given $95 \%$ contribution with a burn-in set of 50,000. For each chain in the IP analysis, each stock's contribution was based on its estimated population size. The Gelman and Rubin shrink factor was used to determine convergence for each chain (Pella \& Masuda, 2001). Stock contributions with a shrink

160 factor of $>1.2$ after 100,000 MCMCs were considered invalid.

\section{Results}


162

163

164

165

166

167

168

169

170

171

172

173

174

175

176

177

178

179

180

181

\subsection{Sample information and DNA extraction}

The dorsal carapace curve length of male individuals was $79.0-88.0 \mathrm{~cm}$ and the curve width was $69.8-81.0 \mathrm{~cm}$. The dorsal carapace curve length of female individuals was $70.0-100.0 \mathrm{~cm}$ and the curve width was $64.0-87.9 \mathrm{~cm}$. The dorsal carapace curve length of juvenile individuals was $32.3-57.0 \mathrm{~cm}$ and the curve width was $27.5-50.0 \mathrm{~cm}$; they weighed $7.75-22.15 \mathrm{~kg}$. The quality of DNA extracted from the samples was high, and the DNA concentration was above 4.8 ng/ $\mu$ l (Table S2).

\subsection{Amplification and detection results of gene loci}

PCR amplification of mitochondrial D-loop gene fragments was successful, and sequencing results were satisfactory. And PCR amplification of the two microsatellites, D1 and B103, was also successful and the type scanning results were good.

The mitochondrial D-loop fragment had nine haplotypes in 19 adults and five haplotypes in 16 juvenile individuals. Microsatellite loci D1 had 11 allele lengths in 19 adults, and nine allele lengths in 16 juvenile individuals. Loci B103 had seven allele lengths in 19 adults and nine allele lengths in 16 juvenile individuals (Table S3).

\subsection{Parentage test results}

By testing the parentage of two microsatellite loci, we found that only two of the 16 juvenile turtles had a possible parent combination. However, the D-loop genotype of the suspected female parent did not match that of the juvenile turtles. As a result, none of the 16 juvenile turtles had a matching parent combination of the 19 adult turtles (Table 1). Therefore, 
182

183

there was no parentage relationship between the 19 adult and 16 juvenile green turtles at the farm.

\subsection{Mixed-stock Analysis}

Among the 19 adult and 16 juvenile green turtles, 11 mitochondrial haplotypes were found.

The CmP57.1 haplotype had the highest frequency, accounting for 34.3\%, followed by CmP20.1, CmP19.1, and CmP49.3, accounting for 11.4\%. In addition, a new haplotype type was found (Table S4).

Both the IP and UP MSA analyses suggested that the majority of stock contribution comes from the Sulu Sea for all datasets (IP 66.54\%; UP 66.45\% juveniles; IP 49.15\%; UP 48.37\% adults, Tables S5 and S6). Moderate stock contributions were shown to come from the Marshall Islands for adults but not juveniles (IP 22.10\%; UP 21.22\% adults; IP 0.21\%; UP 0.21\% juveniles), and moderate contributions came from the Paracel Islands for juveniles, but to a lesser extent for adults (IP 19.79\%; 19.92\% juveniles; IP 3.47\%; UP 3.45\% adults). Juveniles and adults had similar contributions from Wanan Island Taiwan (IP 4.97\%; UP 4.87\% juveniles; IP $4.90 \%$; UP 5.62\% adults). However, the $95 \%$ CI for all stock contributions, except for the Sulu Sea, included zero suggesting these are more of a general estimate than an absolute one (Joseph et al. 2014; Jensen et al. 2016). Nonetheless, $\sim 88 \%$ of stock contributions can be attributed to the Sulu Sea, Marshall Islands, Paracel Islands and Wanan Island. All shrink factors for stock contributions were less than 1.2.

\section{Discussion}

Although this turtle farm claimed that the six adult green turtles bred all the 400 juvenile 
202

203

204

205

206

207

208

209

210

211

212

213

214

215

216

217

218

219

220

221

222

turtles in captivity, no parentage relationship could be identified between the randomly selected

16 juvenile turtles and the six adult green turtles, or even to the other 13 adults. Thus, it is

evident that this farm is dishonest, is illegally farming and trading wild sea turtles, and marketing

them as artificially bred turtles. The more surprising fact is that the farm has a breeding license

issued by the local government. The legal license facilitates the laundering of illegal business in

this case, similar to other cases found in China (Lin et al., 2021). These sea turtles in captivity

may have various illegal overseas sources, their birthplace was mainly the Sulu Sea, followed by

the Marshall Islands, as well as Paracel Islands and Wanan Island in the South China Sea (Fig. 1).

Thus, there is a great possibility that this farm purchased wild turtle eggs or hatchlings from the

above birthplaces through illegal trade chains. Further investigation is warranted to uncover the

detailed source and illegal trade chain by the law enforcement staff.

The huge demand for sea turtles has made China a major market and destination of illegal

trade for a long time, and most traded sea turtles are mainly from fishermen who captured turtles

directly or purchased from dealers in southeast Asian countries (Lam et al., 2011; Gomez \&

Krishnasamy, 2019; Lin et al., 2021). Wild sea turtle populations in the South China Sea and the

Coral Triangle area suffer the most, which has been revealed by mix-stock analysis of sea turtle

samples from the Hainan Islands, China (Gaillard et al., 2020), Brunei Bay and Mantanani,

Malaysia (Joseph et al., 2014; Joseph et al., 2016). The results of the present study are consistent with their findings and provide further evidence on the gravity of illegal turtle fishing and trade in these areas. Our data show juveniles and adults are generally collected from the Sulu Sea, but that hatchlings are more heavily harvested from the Paracel Islands than in adults. However, 
223 adults are being collected from distant rookeries as the Marshall Islands made up over $20 \%$ of

224 their stock contribution. It could be that adult turtles are migrating to the feeding grounds in the

225 Sulu Sea and are being collected there, however, previous analysis of foraging grounds in the

226 Sulu Sea did not find stock contributions from the Marshall Islands (Jensen et al. 2016; Joseph et

227 al. 2016) suggesting these animals were collected from a rookery not found in the Sulu Sea.

228 Therefore, regarding the current sea turtle illegal trade, stricter and more efficient law enforcement is crucial (Lin et al., 2021), and simultaneous monitoring of market trends and trade routes must occur (Lam et al., 2011), multinational cooperation is also required to properly protect green turtles in the South China Sea.

To the best of our knowledge, the present study is the first attempt to use nuclear microsatellite gene combined with mitochondrial gene markers for authenticity testing of artificially bred green turtles in forensic enforcement. The trinucleotide (B103) and tetranucleotide (D1) microsatellite loci used in this study have high genetic diversity and are sufficient to ensure the accuracy of the discrimination results, while the D-loop fragments in mitochondrial DNA are mostly used to identify the origin of sea turtles (Gaos et al., 2017; Hill et al., 2018). Their combination is reliable to rapidly distinguish the authenticity of artificial breeding and also accurately trace the source of the illegal trade or capture of sea turtles.

Meanwhile, the testing is fast and cheap, as the samples can be tested within 48 hours and each sample costs about 200 RMB on average. However, due to limited conditions, only 16 juvenile and 19 adult turtles were sampled in this study, which could be successfully identified using two microsatellite and one mitochondrial loci. But for testing a larger number of samples, it is 
244 recommended to increase the number of of microsatellite loci and use the multiplex PCR method 245 adopted in this study to ensure the accuracy of detection. Microsatellite loci, such as A6, B123,

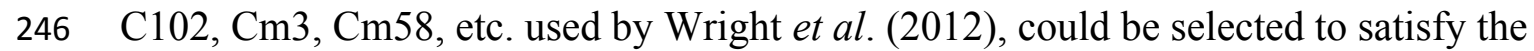

247 identification of more samples. As such, we believe that this method can serve as a good

248 reference for identifying artificially bred green turtles in farms or as part of illegal trade and help

249 obtain reliable evidence of turtle origins in future law enforcement.

\section{Conclusions and conservation implications}

251 The turtle farm investigated in the present study is illegally trading wild sea turtles and 252 marketing them as artificially bred turtles. This method provides reliable evidence for this 253 conclusion and also helps reveal the possible illegal trade chain. As the number of facilities for 254 artificial breeding of sea turtles is expected to gradually increase with the encouragement of 255 artificial breeding of sea turtles, this method could help distinguish the authenticity of artificial 256 breeding in law enforcement and assess its impact on sea turtle populations in future. Moreover, 257 international cooperation between China and Southeast Asian countries should be strengthened 258 to combat the illegal trade of sea turtles and protect their wild populations in the South China Sea 259 and Coral Triangle areas.

260

261

262

\section{Conflicts of interest}

The authors declare no conflicts of interests. 
Ethics Committee of Hainan Provincial Education Centre for Ecology and Environment, Hainan

Normal University (HNECEE-2012-005), which conforms to the Law of People's Republic of

China.

Funding

This work was supported by the National Natural Science Foundation of China (31960101,

31772486), Hainan Natural Science Foundation (319MS048).

\section{Acknowledgments}

We thank the reviewers for their helpful and insightful comments to improve our

manuscript. We are also grateful to L. Kong, R. Li, and D.H. Cheng for their assistance with

DNA extraction.

References

Barbanti A, Martin C, Blumenthal JM, Boyle J, Broderick AC, Collyer L, Ebanks-Petrie G, Godley BJ, Mustin W, Ordóñez V, Pascual M, Carreras C. 2019. How many came home? Evaluating ex situ conservation of green turtles in the Cayman Islands. Molecular Ecology 28:1637-1651 DOI 10.1111/mec.15017.

Bouchard SS, Bjorndal KA. 2000. Sea Turtles as Biological Transporters of Nutrients and Energy from Marine to Terrestrial Ecosystems. Ecology 81:2305-2313.

Bowen BW, Meylan AB, Ross JP, Limpus CJ, Balazs GH, Avise JC. 1992. Global population structure and natural history of the green turtle (Chelonia mydas) in terms of matriarchal phylogeny. Evolution 46:865-881 DOI 10.2307/2409742. 
284

285

286

287

288

289

290

291

292

293

294

295

296

297

298

299

300

301

302

303

304

Chan SKF, Cheng IJ, Zhou T, Wang HJ, Gu HX, Song XJ. 2007. A Comprehensive

Overview of the Population and Conservation Status of Sea Turtles in China. Chelonian

Conservation and Biology 6:185-198 DOI 10.2744/1071-

8443(2007)6[185:ACOOTP $] 2.0 . \mathrm{CO} ; 2$.

Cheng IJ, Dutton PH, Chen CL, Chen HC, Chen YH, Shea JW. 2008. Comparison of the

genetics and nesting ecology of two green turtle rookeries. Journal of Zoology 276:375-384

DOI 10.1111/ j.1469-7998.2008.00501.x.

Chinese Ministry of Agriculture and Rural Affairs. 2019. Notice of the Ministry of

Agriculture and Rural Affairs on Printing and Distributing the Action Plan for the

Protection of Sea Turtles (2019-2033) Nongyufa[2018] No. 31. Bulletin of the Ministry of

Agriculture and Rural Affairs of the People's Republic of China 1:56-56.

Convention on International Trade in Endangered Species of Wild Fauna and Flora. 2019.

Appendices I, II and III, valid from 26 November 2019.

http://www.cites.org/sites/default/files/eng/app/2019/E-Appendices-2019-11-26.

Dethmers KEM, Jensen MP, FitzSimmons NN, BroderickD, Limpus CJ, Moritz C. 2010.

Migration of green turtles (Chelonia mydas) from Australasian feeding grounds inferred from genetic analyses. Marine and Freshwater Research 61: 1376-1387 DOI

$\underline{10.1071 / \mathrm{MF} 10084}$.

Dutton PH, Frey A. 2010. Characterization of polymorphic microsatellite markers for the green turtle (Chelonia mydas). Molecular Ecology Resources 9:354-356 DOI 10.1111/j.17550998.2008.02443.x. 
305

306

307

308

309

Gaillard D, Yeh FC, Lin L, Chen HQ, Zhang T, Luo SJ, Shi HT. 2020. Lost at sea: determining geographic origins of illegally traded green sea turtles (Chelonia mydas) rescued on Hainan Island, China. Wildlife Research, 48: 55-63.

Gao XX, Ye MB, Chen HL. 2015. The first battle of artificial breeding of Guangdong green sea turtles succeeded. Ocean and Fisheries 259:39-40.

Gaos AR, Lewison RL, Jensen MP, Liles MJ, Henriquez A, Chavarria S, Pacheco CM, Valle M, Melero D, Gadea V, Altamirano E, Torres P, Vallejo F, Miranda C, LeMarie C, Lucero J, Oceguera K, Chácon D, Fonseca L, Abrego M, Seminoff JA, Flores EE, Llamas I, Donadi R, Peña B, Muñoz-Pérez JP, Alarcòn D, Chaves JA, Otterstrom S, Zavala A, Hart CE, Brittain R, Alfaro-Shigueto J, Mangel J, Yañez IL, Dutton PH. 2017. Rookery contributions, movements and conservation needs of hawksbill turtles at foraging grounds in the eastern Pacific Ocean. Marine Ecology Progress Series 586:203216 DOI 10.3354/meps12391.

Gomez L, Krishnasamy K. 2019. A Rapid Assessment on the Trade in Marine Turtles in Indonesia, Malaysia and Viet Nam. TRAFFIC. Petaling Jaya, Malaysia. https://www.traffic.org/site/assets/files/12524/se-asia-marine-turtle-trade.pdf (accessed November 2019).

Hamann1 M, Godfrey MH, Seminoff JA, Arthur K, Barata PCR, Bjorndal KA, Bolten AB, Broderick AC, Campbell LM, Carreras C, Casale P, Chaloupka M, Chan SKF, Coyne MS, Crowder LB, Diez CE, Dutton PH, Epperly SP, FitzSimmons NN, Formia A, Girondot M, Hays GC, Cheng IJ, Kaska Y, Lewison R, Mortimer JA, 


\section{Nichols W J, Reina RD, Shanker K, Spotila JR, Tomás J, Wallace BP, Work TM,} Zbinden J, Godley BJ. 2010. Global research priorities for sea turtles: informing management and conservation in the 21st century. Endanger. Species Research 11:245-269.

Hawkes LA, Broderick AC, Godfrey MH, Godley BJ. 2009. Climate change and marine turtles. Endangered Species Research 7:137-154.

Hill JE, King CM, Stewart KR, Paladino FV, Dutton PH. 2018. Genetic differentiation of Hawksbill Turtle rookeries on St. Croix, US Virgin Islands. Chelonian Conservation and Biology 17:303-308 DOI 10.2744/CCB-1293.1.

Huang L, Wang YQ. 2004. The application of microsatellite DNA markers in conservation genetics of endangered animals. Biodiversity 12:58-63.

Jensen MP, Pilcher N, Fitzsimmons NN. 2016. Genetic markers provide insight on origins of immature green turtles Chelonia mydas with biased sex ratios at foraging grounds in Sabah, Malaysia. Endangered Species Research 31: 191-201 DOI 10.3354/esr00763.

Joseph J, Chong YK, Palanlappan PM, Liew HC. 2014. Genetic investigation of green turtles (Chelonia mydas) harvested from a foraging ground at Mantanani, Sabah, Malaysia. Herpetological Conservation and Biology 9:516-523.

Joseph J, Nishizawa H, Arshaad WM, Kadir SAS, Jaaman SA, Bali J, Jamaludin NA, Katoh M. 2016. Genetic stock compositions and natal origin of green turtle (Chelonia mydas) foraging at Brunei Bay. Global Ecology and Conservation 6:16-24 DOI 10.1016/ j.gecco.2016.01.003.

Lam T, Xu L, Takahashi S, Burgess EA. Market forces: An examination of marine turtle trade 
347

348

349

350

351

352

353

354

355

356

357

358

359

360

361

362

363

364

365

366

367

in China and Japan. TRAFFIC East Asia, Hong Kong. 2011.

http://www.trafficchina.org/sites/default/files/traffic_species_reptiles_0.pdf.

Li Feng. 2016. More than 100 endangered green sea turtles lay eggs in Yantai and their babies were born three months later. Sd. Chinaso.com.

http://sd.chinaso.com/tt/detail/20161108/1000200032983981478591582430841795_1.html (accessed 8 November 2016).

Lin L, Li SH, Chen M, Parham JF, Shi HT. 2021. Sea turtle demand in China threatens the survival of wild populations. iScience 24:102517.

Nishizawa H, Abe O, Okuyama J, Kobayashi M, Arai N. 2011. Population genetic structure and implications for natal philopatry of nesting green turtles Chelonia mydas in the Yaeyama Islands, Japan. Endangered Species Research 14:141-148 DOI 10.3354/esr00355.

Parham JF, Shi HT. 2001. The discovery of Mauremys iversoni-like turtles at a turtle farm in Hainan Province, China: The counterfeit golden coin. Asiatic Herpetological Research 9:71-77.

Parham JF, Simison WB, Kozak KH, Feldman CR, Shi HT. 2001. New Chinese turtles: Endangered or invalid? A reassessment of two species using mitochondrial DNA, allozyme electrophoresis, and known locality specimens. Animal Conservation 4:357-367.

Pella J, Masuda M. 2001. Bayesian methods for analysis of stock mixtures from genetic characters. Fishery Bulletin-National oceanic and Atmosperic Administration 99:151-167.

Schlötterer C, Pemberton J. 1994. The use of microsatellites for genetic analysis of natural populations. EXS 69: 203-214. 
368

369

370

371

372

373

374

375

376

377

378

379

380

381

382

383

384

385

386

387

388

Shanker K, Pilcher NJ. 2003. Marine turtle conservation in South and Southeast Asia: hopeless cause or cause for hope? Marine Turtle Newsletter 100:43-51.

Shi HT, Parham JF, Lau M, Chen TH. 2007. Farming endangered turtles to extinction in China. Conservation Biology 21:5-6.

Shimizu TK, Asami K, Yamamoto S, Yoseda DK. 2007. Successful spontaneous nesting of the hawksbill turtle (Eretmochelys imbricata) at Yaeyama Station of National Center for Stock Enhancement (NCSE) in Japan. Proceedings of the international symposium on SEASTAR 2000.

Sizemore E. 2002. The turtle lady: Ila Fox Loetscher of South Padre. Republic of Texas Press, Plano, TX, 231.

Wei WZ. 2016. Research on Conservation Biology of Green Turtle (Chelonia mydas) in the South China Sea. Thesis, East China Normal University.

Wood JR, Wood FE. 1980. Reproductive biology of captive green sea turtles. American Zoologist 20:499-505.

\section{Wright LI, Fuller WJ, Godley BJ, McGowan A, Tregenza T, Broderick AC. 2012.}

Reconstruction of paternal genotypes over multiple breeding seasons reveals male green turtles do not breed annually. Molecular Ecology 21:3625-3635 DOI 10.1111/j.1365294X.2012.05616.X.

Yang WJ. 2015. Analysis on genetic diversity of green turtle (Chelonia mydas) from South China Sea. Thesis, Shandong University.

Yang Zi-Tuo, Liu L. 2014. Application of microsatellite molecular marker techniques in 

aquaculture industry. Guangdong Agricultural Sciences 41:114-116,126.

390

391

392

393

394

395

396

397

398

399

96

Zhang XR, Li FM, Wang LW. 1995. Sexual discrimination of pheasant turtles. Journal of Zoology 1:48-49.

Zhang ZY, Xing XM, Hu PF, Liu SX, Dong YM, Ju GC. 2018. Microsatellite markers and their application in the identification of animal relationships. Genomics and Applied Biology 37:406-1412 DOI CNKI:SUN:GXNB.0.2018-04-007. 


\section{Table $\mathbf{1}$ (on next page)}

Parentage identification results using the direct exclusion method.

*Although there is a suspected parental combination at the microsatellite locus, the D-loop genotype of the suspected parent does not match. 
Table 1. Parentage identification results using the direct exclusion method.

\begin{tabular}{|c|c|c|c|c|c|}
\hline \multirow{2}{*}{$\begin{array}{l}\text { Numberi } \\
\text { ng }\end{array}$} & \multirow{2}{*}{$\begin{array}{l}\text { Females with the same } \\
\text { D-loop genotype }\end{array}$} & \multicolumn{3}{|c|}{ Adult individuals screened by microsatellite loci D1 and B103 } & \multirow[t]{2}{*}{ Identification results } \\
\hline & & Males & Females & $\begin{array}{l}\text { Suspected parent } \\
\text { combination }\end{array}$ & \\
\hline B151 & $\mathrm{A} 03(\mathrm{~F}) / \mathrm{A} 04(\mathrm{~F}) / \mathrm{A} 22(\mathrm{~F})$ & 1 & 1 & 1 & Unmatched parent combination \\
\hline B152 & $\mathrm{A} 03(\mathrm{~F}) / \mathrm{A} 04(\mathrm{~F}) / \mathrm{A} 22(\mathrm{~F})$ & 1 & $\mathrm{~A} 20(\mathrm{~F}) / \mathrm{A} 14(\mathrm{~F}) / \mathrm{A} 04(\mathrm{~F})$ & $\backslash$ & Unmatched parent combination \\
\hline B153 & $\mathrm{A} 03(\mathrm{~F}) / \mathrm{A} 04(\mathrm{~F}) / \mathrm{A} 22(\mathrm{~F})$ & 1 & 1 & $\backslash$ & Unmatched parent combination \\
\hline B154 & 1 & 1 & $\backslash$ & 1 & Unmatched parent combination \\
\hline B155 & 1 & 1 & $\mathrm{~A} 21(\mathrm{~F})$ & 1 & Unmatched parent combination \\
\hline B161 & 1 & 1 & $\mathrm{~A} 13(\mathrm{~F})$ & 1 & Unmatched parent combination \\
\hline B162 & $\mathrm{A} 03(\mathrm{~F}) / \mathrm{A} 04(\mathrm{~F}) / \mathrm{A} 22(\mathrm{~F})$ & A09(M) & $\mathrm{A} 21(\mathrm{~F}) / \mathrm{A} 14(\mathrm{~F}) / \mathrm{A} 07(\mathrm{~F})$ & 1 & Unmatched parent combination \\
\hline B163 & $\mathrm{A} 03(\mathrm{~F}) / \mathrm{A} 04(\mathrm{~F}) / \mathrm{A} 22(\mathrm{~F})$ & $\mathrm{A} 01(\mathrm{M}) / \mathrm{A} 11(\mathrm{M})$ & 1 & 1 & Unmatched parent combination \\
\hline B164 & 1 & $\mathrm{~A} 23(\mathrm{M})$ & $\mathrm{A} 10(\mathrm{~F}) / \mathrm{A} 22(\mathrm{~F}) / \mathrm{A} 16(\mathrm{~F}) / \mathrm{A} 10(\mathrm{~F}) / \mathrm{A} 02(\mathrm{~F})$ & $\mathrm{A} 23(\mathrm{M}) \times \mathrm{A} 10(\mathrm{~F}) / \mathrm{A} 02(\mathrm{~F})$ & Unmatched parent combination* \\
\hline B165 & 1 & 1 & $\mathrm{~A} 16(\mathrm{~F}) / \mathrm{A} 02(\mathrm{~F}) / \mathrm{A} 10(\mathrm{~F})$ & 1 & Unmatched parent combination \\
\hline B166 & $\mathrm{A} 06(\mathrm{~F})$ & 1 & 1 & 1 & Unmatched parent combination \\
\hline B167 & $\mathrm{A} 07(\mathrm{~F})$ & 1 & $\mathrm{~A} 16(\mathrm{~F}) / \mathrm{A} 22(\mathrm{~F}) / \mathrm{A} 23(\mathrm{M})$ & 1 & Unmatched parent combination \\
\hline B171 & $\mathrm{A} 06(\mathrm{~F})$ & $\backslash$ & 1 & $\backslash$ & Unmatched parent combination \\
\hline B172 & $\mathrm{A} 07(\mathrm{~F})$ & $\mathrm{A} 01(\mathrm{M}) / \mathrm{A} 11(\mathrm{M})$ & $\mathrm{A} 06(\mathrm{~F})$ & $\mathrm{A} 11(\mathrm{M}) \times \mathrm{A} 06(\mathrm{~F})$ & Unmatched parent combination* \\
\hline B173 & $\mathrm{A} 07(\mathrm{~F})$ & 1 & $\mathrm{~A} 16(\mathrm{~F}) / \mathrm{A} 02(\mathrm{~F})$ & 1 & Unmatched parent combination \\
\hline B174 & $\mathrm{A} 03(\mathrm{~F}) / \mathrm{A} 04(\mathrm{~F}) / \mathrm{A} 22(\mathrm{~F})$ & $\backslash$ & A01(M)/A09(M) & $\backslash$ & Unmatched parent combination \\
\hline
\end{tabular}

$2 *$ Although there is a suspected parental combination at the microsatellite locus, the D-loop genotype of the suspected parent does not match. 
Figure 1

Map of sea turtles birthplaces, mainly the Sulu Sea, the Marshall Islands, as well as Paracel Islands and Wanan Island in the South China Sea.

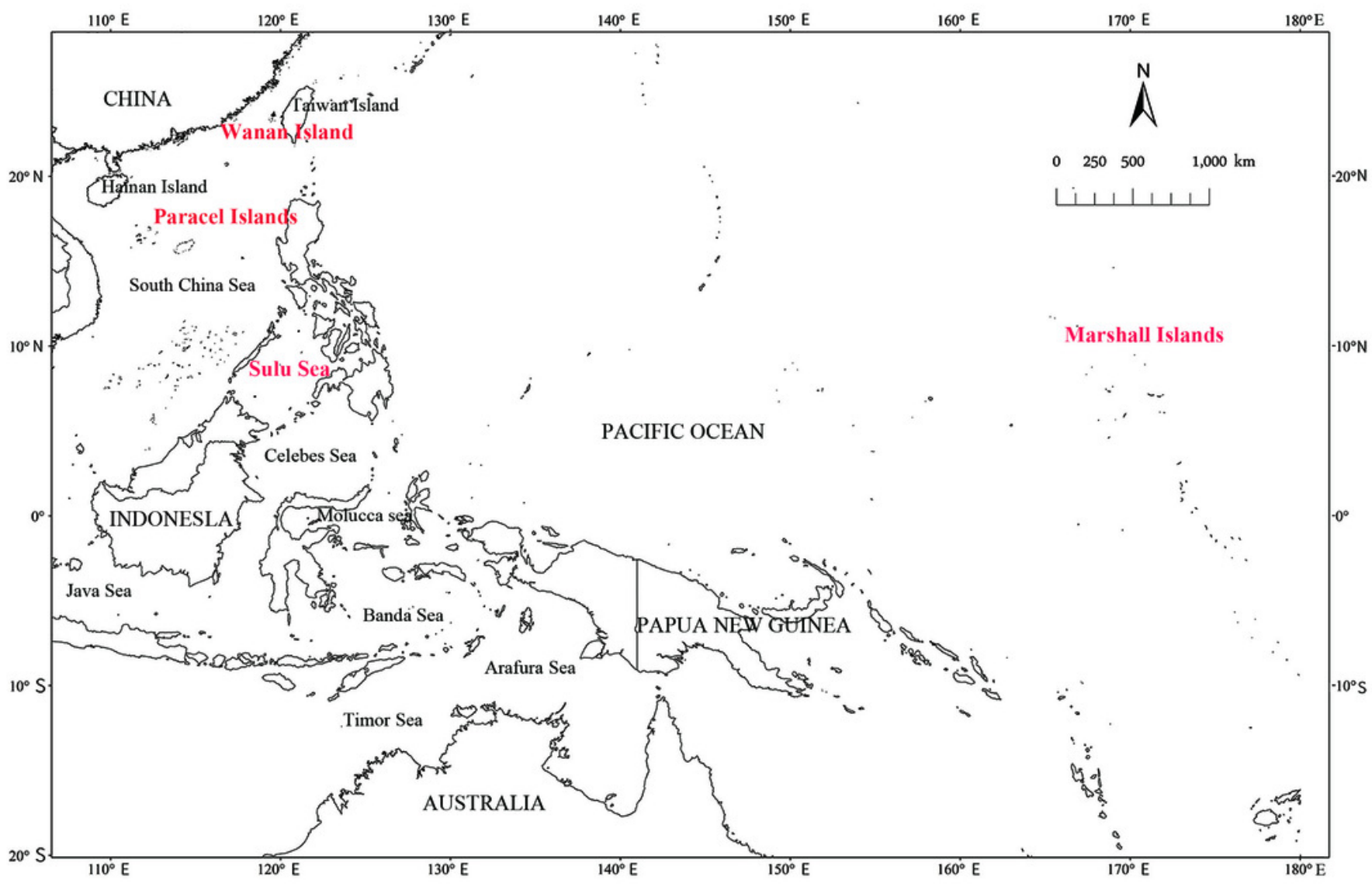

